\title{
Assessment Framework to Select Sustainable Storm Water Management Options for Urban Areas
}

\author{
U.P.L.V. Pathirana ${ }^{1}$, M.T.O.V. Peiris ${ }^{1}$, A. B. Jayasinghe ${ }^{1 *}$, P.K.S. Mahanama ${ }^{1}$ \\ ${ }^{1}$ Department of Town and Country Planning, University of Moratuwa, Katubedda, Sri Lanka
}

\begin{abstract}
Rapid urbanization and land cover changes have increased the quantity of storm water flow in urban areas. In Sri Lanka, local authorities generally prefer conventional drainage solutions rather than providing innovative sustainable solutions in storm water management (SWM). Due to the lack of technological innovations and required standards, development plans prepared by local authorities have not been able to identify alternative practices for storm water management. Hence, this study focuses on the identification of effective and sustainable urban storm water management alternatives in the context of developing countries. Sustainable SWM alternatives that are identified through the literature have been classified under four main sectors i.e. Buildings, Open Spaces, Roads and Sideways. Evaluation is based on the comparative analysis between the existing SWM strategy and alternative SWM strategies under qualitative and quantitative criteria. Analytical Hierarchical Process (AHP) was utilized for the evaluation and the most suitable SWM alternative for urban areas has been selected based on equal weighting and experts' aggregation weighting mechanism. The framework has been tested in the Homagama Divisional Secretariat Division (DSD), Sri Lanka which is one of the fast-growing urban localities in the Colombo District, Sri Lanka. This framework could be adopted for the evaluation of sustainable SWM alternatives for urban areas and is also a useful tool for planners engaged in the preparation of development plans.
\end{abstract}

Keywords: Environmental Sustainability, Strom Water Management, Urban Hydrology, Urban Planning, Method

\section{Introduction}

Rapid urbanization induced land cover changes in urban areas have increased the storm water run-off volumes as well as peak flows (Liu and Jensen, 2018). This phenomenon is experienced in Sri Lanka which has resulted in frequent flash flood events (Battiata, 2010; Jayasinghe et al., 2013). Although hydrology systems and storm water drainage flow have been considered in the process of making development plans in Sri Lanka, sufficient attention is not given for sustainable storm water management (SSWM) practices (Mahanama et al., 2014; Rahman, et al., 2014; Muthu and Santh, 2015; ). Further, most of the urban development plans prepared in Sri Lanka have attempted to address urban flooding and SWM by means of typical centralized storm water drainage network (Mahanama et al., 2014; Ratnayake et al., 2017).
It is argued by many authors that alternative SSWM systems are necessary to mitigate the effects of urban flooding which cannot be achieved by providing centralized storm water drainage network (Goulden et al., 2018). However, application of SSWM practices in developing countries is challenging due to the lack of technical know-how in planning and practice (Loperfido et al., 2014; Cosgrove, et al., 2015). Therefore, there is a need for an effective decision supporting framework to select SSWM alternatives for urban areas in Sri Lanka. This study attempts to develop a framework to select SSWM options for urban areas in Sri Lanka and to evaluate and identify the suitable SSWM options for a selected urban area.

*Corresponding Author

(Dhttps://orcid.org/0000-0002-3268-6428; https://orcid.org/0000-0002-0833-2128

Email address: lakshanivirajani@gmail.com; vishtcp@gmail.com; amilabj@uom.lk; mahanama@uom.lk

DOI: http://doi.org/10.4038/bhumi.v7i2.58 


\section{Methods and Materials}

This study evaluates SSWM alternatives by considering the opinion of experts in the field, literature review and quantitative data analysis. While doing so, it was expected to mainstream the SSWM practices through adopting into development plans prepared by Urban Development Authority (UDA). Analytical Hierarchical Process (AHP) has been utilized to evaluate the alternative systems with existing storm water management (SWM) techniques under four (04) sectors namely: Buildings, Open Spaces, Roads and Sideways.

This study has two (02) key outputs. The first output is the development of a framework to select suitable SSWM alternative for urban areas and the second output is the application of suitable SSWM alternative for a selected case study in Sri Lanka. The case study used is Homagama Pradeshiya Sabha area which is located in the Colombo District, Sri Lanka with the potential for urbanization. The methodology followed in the study has been illustrated in Figure 1. Expert opinion has been used to derive SSWM alternatives under 04 main sectors as identified in the literature. In this situation, alternatives are compared with the existing SWM technique used in urban areas in Sri Lanka under each sector.

Understanding the SWM and characteristics of storm water are critical for assessing the suitability of SWM - especially in urban areas. In Sri Lanka, comparatively a few articles have been published to understand SSWM alternatives and there is a timely need to understand the characteristics, relationships and roles of the storm water in urban areas.

Alternative SWM practices are important to improve the water quality and to increase the restoration capacity. Due to land use changes induced by rapid urbanization, there is an increase of storm water runoff and water logging in urban areas. By using the conventional drainage practices, SSWM cannot be achieved (Barbosa, et al., 2014) There are various alternative SWM practices that are identified through the literature review and it is evident that effectiveness of SSWM alternatives is different from one to another (Berland, et al. 2017). Based on the literature review, there are different criteria and indicators listed in the international context. By considering the Sri Lankan conditions and accessible technology,
SSWM alternative selection criteria has been limited to a few measurable indicators. The selected criteria for the study has been listed in Table 1. The evaluation criteria were based on the similar case studies in global context with similar issues related to SWM. Experts' discussions are used to shortlist the criteria and those criteria has been divided into eight qualitative criteria and three quantitative criteria. The alternatives selected are under four main sectors of Roads, Open Spaces, Sideways and Buildings. Alternatives are assumed as it applies $100 \%$ of the area and compares with the existing situation. Experts' opinion is used for the

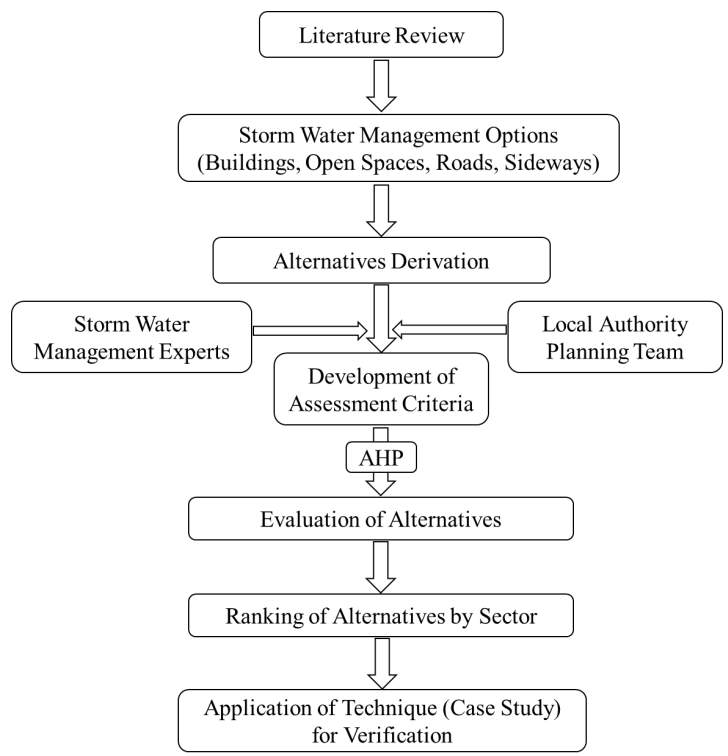

derivation of alternative techniques. (Table 2).

Figure 1. Adopted Methodology for the Study

The parameters used for the quantitative criteria are Capital Cost, Annual Operation and Management Cost estimation and the runoff reduction rate. The initial cost and the operation and maintenance cost were decided using literature and the experience of members who are engaged in action projects in the planning team of the Urban Development Authority and the Local Authority. All the costs are converted to Sri Lankan Rupees (LKR). The initial cost estimate for 1 square meter and the Operation and Maintenance cost for 1 square meter per month are assumed. (Table 3).

Runoff Calculation is completed by using the Rational Formula. The existing runoff is calculated for the four main sectors (Roads, Buildings, Sideways and Open Spaces.) Calculation of the runoff reduction of different alternatives has been conducted by using the literature review. The final outcome is a rate of runoff reduction from each alternative. 
Table 1. Criteria that use for storm water Management

\begin{tabular}{|l|l|}
\hline \multicolumn{1}{|c|}{$\begin{array}{c}\text { Storm water } \\
\text { Management } \\
\text { Criteria for Option/ } \\
\text { Alternative } \\
\text { Selection* }\end{array}$} & \multicolumn{1}{c|}{$\begin{array}{c}\text { Surface runoff } \\
\text { reduction and } \\
\text { Environmental impact* }\end{array}$} \\
\hline Volume & Bio decay \\
\hline $\begin{array}{l}\text { Effects on Water } \\
\text { Quality }\end{array}$ & Denitrification \\
\hline Acceptability & Area Requirement \\
\hline System Complexity & Willingness to Pay \\
\hline Peak Discharge & Plant uptake \\
\hline Flood control & Coliform die off \\
\hline Peak flow reduction & Precipitation adsorption \\
\hline Amenity \& aesthetics & Evapotranspiration \\
\hline Initial Cost & Filtration \\
\hline $\begin{array}{l}\text { Public Health \& } \\
\text { safety, risks }\end{array}$ & $\begin{array}{l}\text { Erosion control and } \\
\text { sedimentation }\end{array}$ \\
\hline Adaptability & Infiltration \\
\hline Pollution control & $\begin{array}{l}\text { Effectiveness of Ground } \\
\text { Water Recharge }\end{array}$ \\
\hline
\end{tabular}

Sources: *Authors constructed based on (Fila, et al. 2009; Apfelbaum, 1983; Shutes, 2001)

Table 2. Alternatives under Main Sectors

\begin{tabular}{|c|c|c|}
\hline $\begin{array}{l}\text { Main } \\
\text { Sector }\end{array}$ & Alternative options & $\begin{array}{c}\text { Runoff } \\
\text { reduction } \\
\%^{*}\end{array}$ \\
\hline \multirow{4}{*}{ 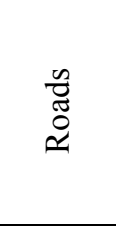 } & Base Situation & 0 \\
\hline & $\begin{array}{l}\text { Permeable Interlocking } \\
\text { Concrete Pavement }^{\#}\end{array}$ & 45 \\
\hline & Pervious Concrete $^{\#}$ & 40 \\
\hline & Porous Asphalt & 0 \\
\hline \multirow{4}{*}{ 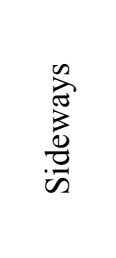 } & Base Situation & 0 \\
\hline & $\begin{array}{l}\text { Infiltration } \\
\text { Trenches/Strips }\end{array}$ & 70 \\
\hline & $\begin{array}{l}\text { Infiltration Planter/ Rain } \\
\text { Garden }^{\#}\end{array}$ & 40 \\
\hline & Soak Ways ${ }^{\#}$ & 65 \\
\hline \multirow{7}{*}{ 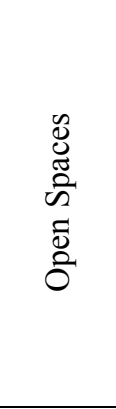 } & Base Situation & 0 \\
\hline & Wetland $^{\#}$ & 50 \\
\hline & $\begin{array}{l}\text { Infiltration Planter/ Rain } \\
\text { Garden }\end{array}$ & 0 \\
\hline & Retention Ponds $^{\#}$ & 10 \\
\hline & Urban Forests Buffers $^{\#}$ & 34 \\
\hline & $\begin{array}{l}\text { Wet Detention } \\
\text { (Ponds/Lake) }^{\#}\end{array}$ & 32 \\
\hline & Dry Detention Basins ${ }^{\#}$ & 0 \\
\hline \multirow{3}{*}{ 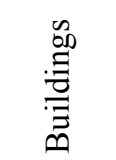 } & Base Situation & 15 \\
\hline & Green Roof $100 \%$ & 70 \\
\hline & Rain Barrel 100\% & 15 \\
\hline
\end{tabular}

Sources: *Authors constructed based on (Barbosa, et al. 2012; Abenayake, et al. 2018) Note: \# at $100 \%$ coverage

$$
\mathbf{Q T}=\mathbf{C} * \mathbf{i T} * \mathbf{A}
$$

Wherein:

QT = estimate of the peak rate of runoff (cfs) for some recurrence interval, $\mathrm{T}$

$\mathrm{C}=$ runoff coefficient

$\mathrm{iT}=$ Average rainfall intensity (in/hr) for some recurrence interval, $\mathrm{T}$, during that period of time equal to the Tc

$\mathrm{A}=$ the contributing drainage area (acres) to the point of design that produces the maximum peak rate of runoff

Quantification for the qualitative criteria was conducted by using Experts' opinions. Analytical Hierarchical Process (AHP) is one of the methods that have been used to obtain prioritization of experts' opinions. Eighteen alternatives of four sectors are evaluated under eight qualitative criteria using the AHP technique based on opinions of fifteen experts in the fields of SWM industry - research and academic. Criteria that have been used for the study are system adaptability, system complexity, the effectiveness of groundwater recharge, area requirement, effects on water quality, aesthetic \& amenity, acceptability and willingness to pay. Experts were asked to provide their opinion using AHP and give a score for the criteria. The scale is given to score the alternatives by using pairwise comparison. The pairwise comparison was conducted by using the given criteria and the consistency level was under $10 \%$. AHP diagrams have been created for each main sector and there were eight sheets for eight criteria to evaluate the alternatives under the main sectors - namely: Buildings, Open Spaces, Roads \& Sideways (Table 5). The qualitative data analysis has been quantified by getting the average of all the results of experts and giving an equal weight to criteria to evaluate the alternatives. And experts' aggregation weights were also given to prioritize the sector-wise alternatives.

The case study area, Homagama Pradeshiya Sabha (PS) is situated along the High-Level Road about $21 \mathrm{Km}$ away from the City of Colombo, Sri Lanka which includes 91 Grama Niladhari Divisions. The total land extent of Homagama PS area is 138.2 sq. km. Land use changes are evident in Homagama where rubber and paddy lands have been converted into residential use, due to increasing population. The pervious area has been decreased and impervious areas are increasing due to the recent development trend in the area. Because of the land use change, urban areas in Homagama get affected by localized flood situations, both flash floods and riverine floods. 
Table 3. Cost Estimation for One square meter

\begin{tabular}{|l|c|c|}
\hline \multicolumn{1}{|c|}{ Alternative Options } & $\begin{array}{c}\text { Initial Cost } \\
\text { 1 sq. m. (LKR) }\end{array}$ & $\begin{array}{c}\text { O \& M Cost } \\
\text { 1 sq. m. (LKR) }\end{array}$ \\
\hline Green Roof & $4,600.00$ & 230.00 \\
\hline Rain Barrel & 92.00 & 46.00 \\
\hline Wetland & 188.50 & 8.48 \\
\hline Infiltration Planter/ Rain garden & $2,615.00$ & 117.68 \\
\hline Retention Ponds & $18,988.00$ & 189.88 \\
\hline Urban Forests Buffers & $22,961.00$ & $1,377.66$ \\
\hline Wet Detention (Ponds/ Lakes) & $1,033.00$ & 10.33 \\
\hline Dry Detention Basins & $11,850.00$ & 118.5 \\
\hline permeable Interlocking Concrete Pavement & $19,780.00$ & $9,890.00$ \\
\hline Porous Asphalt & $11,565.00$ & $5,782.50$ \\
\hline Pervious Concrete & $15,535.00$ & $7,767.50$ \\
\hline Infiltration Trenches/Strips & $6,041.00$ & 724.92 \\
\hline Infiltration Planter/ Rain garden & $2,615.00$ & 130.75 \\
\hline Soak Ways & $15,517.00$ & 931.02 \\
\hline
\end{tabular}

The development plan for Homagama PS has identified Homagama to be free from disasters for the future population. To achieve this objective SWM plays a vital role in Homagama PS area. With the challenge of providing additional housing for the increasing population, the impervious area could be significantly increased, leaving a small space for greenery and SWM. There is a network of natural drains in the city area that discharge storm water but these drains are now incapable of storm water runoff due to increasing impervious areas.

\section{Analysis \& Results}

The analysis to identify SSWM strategy is twofold: evaluation of quantitative criteria and evaluation of qualitative criteria by using AHP technique. Upon selection of SSWM alternative through qualitative and quantitative techniques, it is applied for the case study area. Based on the identified cost of alternative SWM strategies, total initial cost and Operation \& Maintenance (O\&M) cost has been calculated assuming the alternative strategy is applied for the whole area of each sector. Based on this analysis, Green Roof records the highest initial cost and $\mathrm{O} \& \mathrm{M}$ cost in the 'building' sector. In the 'open spaces' sector, the highest cost is for urban forests. In the 'roads' sector, permeable interlocking pavements are taking the highest capital cost and the maintenance cost. Soak ways are much costlier to install and maintain than infiltration trenches and rain gardens in the 'sideways' sector. To obtain the values, land area of Homagama PS Area is used which is the land cover of buildings network, open spaces, road network and sideways. Runoff reduction was calculated for each alternative under key sectors. The key assumption used here is that $0 \%$ runoff reduction in the existing scenario is compared with the alternative used in each sector. According to the runoff reduction rates, green roofs can reduce the runoff better than the rain barrel system in the building sector; rain gardens and urban forests can reduce the runoff than the other alternatives in open space sector. In the road sector, runoff reduction rate is high in porous asphalt $\&$ pervious concrete. In the sideways sector, rain gardens can reduce the runoff rate better than soak ways and infiltration strips. The difference between sectors are visualized in bar graphs.

The average of all the scores for alternatives are calculated based on the experts' survey conducted for AHP. The eight criteria of the qualitative side are evaluated under experts' scores with the pairwise comparison. If the consistency level exceeds $10 \%$ of any sheet, it is considered as a rejected answer sheet. The total values of the alternatives are weighted to check the sensitivity of the ranking. The alternatives are weighted by equal score and expert Weight of the criteria (Table 4). Alternatives were ranked according to the Equal weights scores and Experts' aggregation score under sectors (Table 5).

According to the final weighted scores of the alternatives, the highest ranked alternative is highlighted in both weighted scores. In the Building sector and Open spaces sector, the outcome of weighted scores are different but in the roads and sideway sectors, the results are same. The different alternatives of different 
sectors are depicted in Table 5. In the building sector, Green Roof and Rain barrels are better than the current situation to manage the storm water.

Table 4. Equal Weight and Experts' Aggregation Weights

\begin{tabular}{|cl|c|c|}
\hline \multicolumn{1}{|c|}{ Criteria } & $\begin{array}{c}\text { Equal } \\
\text { weight }\end{array}$ & $\begin{array}{c}\text { Experts' } \\
\text { Weights }\end{array}$ \\
\hline 1. & Acceptability & 0.09 & 0.036 \\
\hline 2. & $\begin{array}{l}\text { Amenity and } \\
\text { aesthetics }\end{array}$ & 0.09 & 0.046 \\
\hline 3. & $\begin{array}{l}\text { Annual O\&M } \\
\text { Cost }\end{array}$ & 0.09 & 0.138 \\
\hline 4. & Area Requirement & 0.09 & 0.055 \\
\hline 5. & $\begin{array}{l}\text { Effectiveness of } \\
\text { Ground Water } \\
\text { Recharge }\end{array}$ & 0.09 & 0.098 \\
\hline 6. & $\begin{array}{l}\text { Effects on Water } \\
\text { Quality }\end{array}$ & 0.09 & 0.071 \\
\hline 7. & Initial Cost & 0.09 & 0.18 \\
\hline 8. & Runoff Reduction & 0.09 & 0.088 \\
\hline 9. & $\begin{array}{l}\text { System } \\
\text { Adaptability }\end{array}$ & 0.09 & 0.053 \\
\hline 10. & $\begin{array}{l}\text { System } \\
\text { Complexity }\end{array}$ & 0.09 & 0.049 \\
\hline 11. & $\begin{array}{l}\text { Willingness to } \\
\text { Pay }\end{array}$ & 0.09 & 0.052 \\
\hline
\end{tabular}

By the equal weight, the Green Roof comes as the better solution for Homagama to manage the storm water. But experts' opinions indicate that Rain barrel system is the most suitable alternative for storm water management in Buildings. Rain Barrel System is effective in ground Water recharging and for that, the new area requirement is less and the cost lower than the green roof system. However, when the acceptability and aesthetics are considered, the green roofs are at a higher level than the Rain barrel. According to the literature reviews and the planning team of the Homagama PS, Rain barrels are some kind of a symbol of the poor. People tend to think that a home barrel system will degrade their status in society. But rain barrels can reduce the runoff by discharging the water in off-peak time (Figure 2). According to the radar chart, Rain garden is in the highest range of effectiveness of groundwater recharge, the area requirement and the effects on water quality. But the willingness to pay for the system is less than for the other alternatives. Rain garden is followed by urban forest, but the cost of annual operation and management cost and the initial costs are higher than the rain gardens. but the system adaptability is low. Dry detention basin take average scores in all criteria and the effectiveness of groundwater recharge is also lower than rain garden.

Table 5. SWM alternative ranking according to the Sectors

\begin{tabular}{|c|c|c|c|c|c|}
\hline Sectors & Alternatives & $\begin{array}{l}\text { Equal } \\
\text { Weight }\end{array}$ & Rank & $\begin{array}{l}\text { Experts } \\
\text { Aggregation }\end{array}$ & Rank \\
\hline \multirow[t]{3}{*}{ Building } & Base Status Quo & 0.12500 & 3 & 0.08186 & 3 \\
\hline & Green Roof & 0.31897 & 1 & 0.19383 & 2 \\
\hline & Rain Barrel & 0.30498 & 2 & 0.20637 & 1 \\
\hline \multirow[t]{7}{*}{ Open Spaces } & Base Status Quo & 0.03504 & 7 & 0.02135 & 7 \\
\hline & Wetland & 0.13316 & 2 & 0.08341 & 4 \\
\hline & $\begin{array}{l}\text { Infiltration Planter/ Rain } \\
\text { garden }\end{array}$ & 0.17052 & 1 & 0.11997 & 6 \\
\hline & Retention Ponds & 0.14264 & 5 & 0.13349 & 2 \\
\hline & Urban Forests Buffers & 0.16880 & 5 & 0.18295 & 1 \\
\hline & $\begin{array}{l}\text { Wet Detention (Ponds/ } \\
\text { Lakes) }\end{array}$ & 0.11166 & 6 & 0.07458 & 5 \\
\hline & Dry Detention Basins & 0.13656 & 4 & 0.11500 & 3 \\
\hline \multirow[t]{4}{*}{ Roads } & Base Status Quo & 0.11990 & 4 & 0.07086 & 4 \\
\hline & $\begin{array}{l}\text { permeable Interlocking } \\
\text { Concrete Pavement }\end{array}$ & 0.21204 & 2 & 0.15698 & 2 \\
\hline & Porous Asphalt & 0.21034 & 3 & 0.14698 & 3 \\
\hline & Pervious Concrete & 0.26290 & 1 & 0.18403 & 1 \\
\hline \multirow[t]{4}{*}{ Side Ways } & Base Status Quo & 0.07759 & 4 & 0.04522 & 4 \\
\hline & $\begin{array}{l}\text { Infiltration } \\
\text { Trenches/Strips }\end{array}$ & 0.25872 & 1 & 0.16799 & 1 \\
\hline & $\begin{array}{l}\text { Infiltration Planter/ Rain } \\
\text { garden }\end{array}$ & 0.23878 & 2 & 0.15209 & 2 \\
\hline & Soak Ways & 0.18606 & 3 & 0.11951 & 3 \\
\hline
\end{tabular}


Wetlands are acceptable and it has more aesthetic value but not effective in groundwater recharge and it takes a large area to install. Wet detention basins have considerable value for groundwater recharge, aesthetics, and acceptability but wet detention basins do not reduce the runoff rate (Figure 2). For roads, the alternative is the permeable pavement. But permeable pavement types are different from one to another by their function. All the three types of permeable pavement are not effective in runoff reduction. But the effectiveness of the groundwater discharge is the same in three types. But the acceptability and the willingness to pay is the higher value in pervious concrete. (Figure 2). For walkways, infiltration trenches have got higher values in effectiveness of groundwater recharging, effects on water quality and for system adaptability. Willingness to pay for soak ways is higher than other alternatives. Rain garden got the higher value in aesthetic and the acceptability to Homagama area than other alternatives. Infiltration trenches are followed by the rain garden (Figure 2).

\section{Conclusion}

In developing countries, there is always a challenge to select a suitable sustainable alternative to manage storm water. This study has attempted to address this issue by evaluating sustainable storm water management practices by using a balanced framework. The alternatives are divided into four sectors according to experts' discussions as Buildings, Roads, Open Spaces and Walkways. Under these sectors, the existing storm water management technique is also considered as an alternative. So other alternatives under each sector can easily be compared within. In the evaluation, it is assumed that the alternative had applied for $100 \%$ of the selected sector area. Also, the framework included qualitative and quantitative criteria to evaluate the selected sustainable alternatives. The quantitative criteria are evaluated by estimations and calculation of the construction and management of SWM practices while the qualitative criteria are evaluated by using experts' opinions using Analytical Hierarchical Process. The results are again weighted according to experts' opinion and also by giving equal weights.

Homagama, which is an upcoming residential area is selected as the case study area to test the framework. With the increasing residential demand, a decrease of marsh lands and paddy
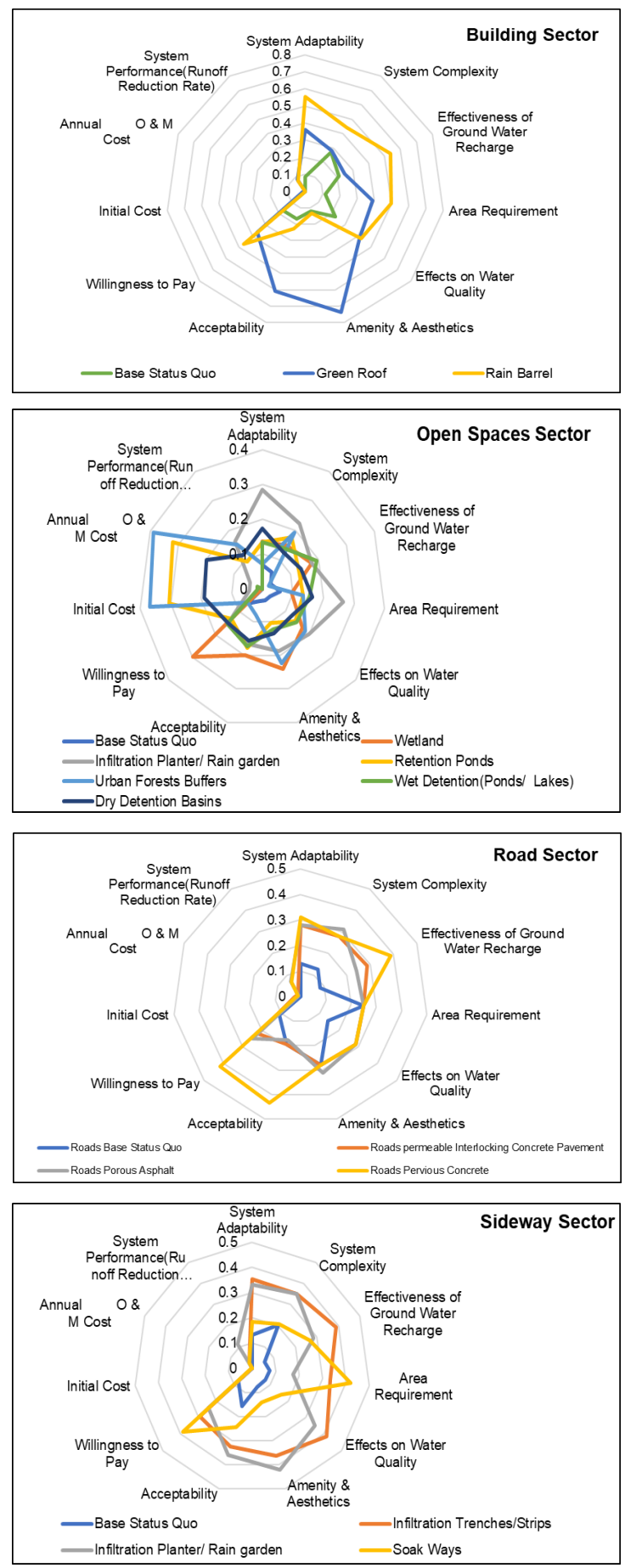

Figure 3. Storm water Management Alternative by Sectors

lands are evident, resulting in occasional local/ urban floods in the urban area in Sri Lanka (Abenayake, et al., 2018). In order to address this issue, a framework has been applied to find a suitable SSWM alternative. The results are obtained in four sectors. For the buildings, green roof system is the suitable alternative according to the equal weights and also based on experts' opinion, rain barrel system is the sustainable alternative for Homagama. For the open spaces, expert opinion is to use urban forests as the suitable alternative and suitable alternative is 
the Infiltration Planters/ Rain garden when the equal weights are given. For roads, the equal weight and the experts' weight are to the pervious concrete pavements. For sideways infiltration filters/strips are suitable options according to both weighting categories.

This study can be further used to select the suitable storm water Management alternative for local authority area, by application of the framework in the development plan making process. This study can be validated by applying in various context specific urban areas with different results to mainstream the SSWM into the planning process. The results are solely evaluated by using equal weights and expert aggregation weights. But this study could be evaluated by using more weighted criteria and can get the suitable option among the alternatives. There were few limitations in conducting this research. Firstly, this study is based on experts' opinions, secondary data as well as experience in the field. The results are interpreted according to some assumptions and methodologies. Secondly, all the alternatives and criteria may change according to the climatic inputs. Also in countries like Sri Lanka, storm water managers, engineers, and contractors may have limited experience/ expertise with these new solutions. Costs for alternatives are not detailed in depth. Costs are difficult to quantify by field data and literature review. Limited criteria have been used in this study because of the lack of data and short study time period. There are three quantitative criteria and 8 qualitative criteria. Those criteria are divided for qualitative and quantitative criteria by referring to similar assessments. Finally, this study only used 15 experts who are involved in the planning, academia, and contracting fields.

\section{References}

Abenayake, C. C., Mikami, Y., Matsuda, Y., \& Jayasinghe, A. (2018). Ecosystem services-based composite indicator for assessing community resilience to floods. Environmental development, 27, 34-46. https://doi.org/10.1016/j.envdev.2018.08.002

Abenayake, C. C., De Silva, K. I. U. T., \& Mahanama, P. K. S. (2018). Rainwater Harvesting Innovations for Flood-Resilient Cities.

Apfelbaum, S. I. (1983). Applied Ecological• Services. Raptor Research, 17(4), 97-113.

Barbosa, A. E., Fernandes, J. N., \& David, L. M. (2012). Key issues for sustainable urban storm water management. Water research, 46(20), 6787-6798. https://doi.org/10.1016/j.watres.2012.05.029

Battiata, J., Collins, K., Hirschman, D., \& Hoffmann, G. (2010). The runoff reduction method. Journal of Contemporary Water Research \& Education, 146(1), 11-21. https://doi.org/10.1111/j.1936-704X.2010.00388.x

Berland, A., Shiflett, S. A., Shuster, W. D., Garmestani, A. S., Goddard, H. C., Herrmann, D. L., $\&$ Hopton, M. E. (2017). The role of trees in urban storm water management. Landscape and Urban Planning, 162, 167-177. https://doi.org/10.1016/j.landurbplan.2017.02.017

Cosgrove, W. J., \& Loucks, D. P. (2015). Water management: Current and future challenges and research directions. Water Resources Research, 51(6), 4823-4839. https://doi.org/10.1002/2014WR016869

Fila, A. A., \& Shahab, S. Application of Recreational Spaces in Fulfilling Collaborative Planning GoalsA case study of Bandar Abbas city in southern Iran.

Goulden, S., Portman, M. E., Carmon, N., \& Alon-Mozes, T. (2018). From conventional drainage to sustainable storm water management: Beyond the technical challenges. Journal of environmental management, 219, 37-45. https://doi.org/10.1016/j.jenvman.2018.04.066

Jayasinghe, A. B., Mahanama, P. K. S., Senanayake, D. L., Bandara, L., \& Seifert, I. (2013). Participatory GIS (PGIS) as a tool for Flood Mapping in climate change adaptation: a study of Batticaloa city, Sri Lanka. 
Liu, L., \& Jensen, M. B. (2018). Green infrastructure for sustainable urban water management: Practices of five forerunner cities. Cities, 74, 126-133. https://doi.org/10.1016/j.cities.2017.11.013

Loperfido, J. V., Noe, G. B., Jarnagin, S. T., \& Hogan, D. M. (2014). Effects of distributed and centralized storm water best management practices and land cover on urban stream hydrology at the catchment scale. Journal of Hydrology, 519, 2584-2595. https://doi.org/10.1016/j.jhydrol.2014.07.007

Mahanama, P. S., Abenayake, C. C., \& Jayasinghe, P. (2014). Challenge of local responses to climate change; perceptions of urban planning practitioners in Sri Lanka. Asian Journal of Humanities and Social Studies, 2(4).

Muthu, A. L., \& Santhi, M. H. (2015). Estimation of surface runoff potential using SCS-CN method integrated with GIS. Indian Journal of Science and Technology, 8(28), 1-5. https://doi.org/10.17485/ijst/2015/v8i28/83324

Shutes, R. B. E. (2001). Artificial wetlands and water quality improvement. Environment international, 26(5-6), 441-447. https://doi.org/10.1016/S0160-4120(01)00025-3

Rahman, M., Saha, R., Haque, M. M., \& Hossain, S. Storm water Management for Urban Areas of Bangladesh by Analytical \& Modelling Approach: A Case Study of Chalna Municipality.

Ratnayake, R., Wickramaarachchi, N., \& Wattege, P. (2017). Urban water body recreational development and revitalizing program in Sri Lanka: public perception and willingness to pay. Bhumi, The Planning Research Journal, 5(2). https://doi.org/10.4038/bhumi.v5i2.30 